Logos Universality Mentality Education Novelty, Section: Philosophy and Humanistic Sciences

ISSN: 2284-5976 (print), ISSN: 2284-5976 (electronic)

Covered in: CEEOL, Index Copernicus, Ideas RePEc, EconPapers, Socionet

\title{
THE PORTRAIT. A POSSIBLE CONNECTION BETWEEN PSYCHOLOGY AND ART
}

\section{Irina-Andreea STOLERIU}

Logos Universality Mentality Education Novelty, Section:

Philosophy and Humanistic Sciences, III (1), 139-148

The online version of this article can be found at:

http://lumenjournals.com/philosophy-and-humanisticsciences/

Published by:

Lumen Publishing House

On behalf of:

Lumen Research Center in Social and Humanistic Sciences 


\title{
The Portrait. A Possible Connection between \\ Psychology and Art
}

\section{Irina-Andreea STOLERIU ${ }^{1}$}

\begin{abstract}
This research intends to render the main aspects of the connection between psychology and art by means of psychological portrait. From remote times, it offered artists the possibility of understanding and rendering their models' feelings by transposing their features and emotions into an artistic form. Throughout history, this type of portrait has received the attention of artists, who bave shown that they have a keen interest in the psychological field, integrating in their works their knowledge on the characteristics and inner movements of the portrayed characters. All these action have been made possible by overcoming the formal threshold of the representation of physiognomic features and reaching their psycho-moral levels. In this respect, the creators' aim has been that of rendering specific interdisciplinary issues related to the affective and imaginary level connections between the shape of one's face and countenance, as well as the links between the manifested emotions and facial, gestural and body expressions, thus offering a visual interpretation of the personality of the portrayed person. Moreover, this study intends to offer a new and contemporary interpretation leading the way to a different type of understanding and depiction of the buman countenance, based on the exploration of new ways of becoming acquainted with the buman psyche and body.
\end{abstract}

\section{Keywords:}

portrait, art, personality, psychology, physiognomy.

${ }^{1}$ PhD Lecturer, "G. Enescu” University of Arts, Faculty of Visual Arts and Design, Iaşi, Romania, andreea_stoleriu@yahoo.com, 0745.05.14.88.

Stoleriu, I-A. (2015). The Portrait. A Possible Connection between Psychology and Art. Logos, Universality, Mentality, Education, Novelty - Section Philosophy and Humanistic Sciences, III (1), 139-148. 


\section{Introduction}

In this study, we will provide details on psychological portraits, the focus being both on artistic and psychological representations which have offered the artist the possibility of understanding and capturing the models' feelings, transposing their features and emotions into an artistic form. The definition of the term of "portrait" has as a starting point two major semantic dimensions, such as the work of art itself, respectively the artistic type which may be different depending on the topic of the work of art, in historic painting, a specific genre scene, landscape and still life. Based on the different meanings and definitions provided in time, we propose two meanings of the term "portrait". Thus, to a broader extent, the portrait refers to any artistic representation of the human face more or less faithful to the model. Concurrently, the second vision on this notion sheds light on a reduced meaning of the term under discussion, concretized by a true to reality rendering and individualization of the portrayed character both from a physical and psychic point of view.

The art historian Nadeije Laneyrie-Dagen mentioned that "in the bierarchy of genres, the portrait has an ambiguous place" (Laneyrie-Dagen, 2004, p. 32). The importance and complexity of this genre marks one of the main trajectories that the continuously transforming art has known in time, through the change of vision of reality and through the transformations of the terms portrait and portraiture. In the long period of time since it appeared, the genre of portrait has known major changes, caused by various factors, such as social, political, scientific and last, but not least, artistic evolution.

\section{Mimesis}

In the case of portraiture, the idea of imitation (mimesis) has in view the documentary character of a work of art, the focus being on capturing the model's personality and the placement in one's specific social, economic and cultural context. Just like the art historian Shearer West has mentioned, the genre of portrait can be "bistorically linked to the idea of «mimesis» or resemblance" (West, 2004, p. 12), its role being that of catching and preserving the specific physiognomy features, sometimes appealing to the idealization of the portrayed face. Along history, the idea of imitation could not always be interpreted only as a process of 
copying one's physiognomy, it sometimes catches the personality of the model also, one's bodylanguage or one's manner of moving. In this respect, some theories have suggested the fact that the main role of body movements was that of revealing one's hidden qualities of the soul, the observation of gestures proved to be a very useful thing while creating portraits (Perkinson, 2009, p. 48). This so-called usefulness was necessary for the accurate perception of the model, both from the perspective of the artist, who had to captue one's features and also from the one of the viewer who, through the intervention of the creator, connected to the portrayed character. Some of the portraitists made themselves appreciated through the way in which they managed to catch the physiognomic features of the rendered characters or through the refinement of the chosen chromatic, but they did not fully involve in the aspects of their psychological understanding. In return, some have also become known particularly due to this aspects, by being able to understand the model and going beyond one's physiognomy, trying to underline one's inner qualities.

\section{Physiognomy and morfopsychology}

The issues related to the portrait have been often related to psychology, through scientific fields, such as physiognomy and morphopsychology. Louis Corman, Roger Mucchielli and Patrice Ras are only a few of the most important researchers passionate about morphopsychological studies. From the point of view of this science, the portrait is "the description of a personality starting from one's face shape"; the portraiture method implies three defining stages: observation, interpretation and expression. The definition given to the portrait in morphopsychology points out the physical aspect related to the model's personality, starting from certain patterns set in time due to great personalities in this field, among whom the most important is the inventor of this science - the French psychiatrist Louis Corman (19011995).

These scientific features open up new horizons of knowledge and interpretation for portraiture, this specific science proved to be useful both for the creator and for the viewer, they could both benefit from understanding the complexity of the relationship among the model's character, specificity and personality. Referring to the above 
mentioned ideas, the artist has the role of interfering in the raw material, out of which the individual's specific features emerge, offering unicity to one through a series of essential elements which reveal one's identity (West, 2004, p. 21). Consequently, in the character's representation, the designer, painter or sculptor can be preoccupied both by exterior aspects, such as the resemblance with the model, but also by inner ones, transposed in catching a particular state or attitude which can be identified on one's face.

According to Paula Onofrei, when we enter the "house of fiction", we see not one window, but a million, every one of which has been pierced and is still pierceable by the need of the individual vision or by the presence of the individual will. Furthermore, she underlines the fact that perception plays a vital role in the process of creation: "people may read the same books, but one sees more where the other sees less it is a question of individual perception" (Onofrei, 2009, pp. 325-326), also connected to Husserl's metaphor of the cube: in space, we see only one facet, maybe two, but never the figure as a whole. By paraphrasing Paula Onofrei's statement,"people interpret literature according to their subjective perception", based on the tripartite relation author -text reader, which supposes the existence of a transfer of identity, most often univocal, we could say that artists interpret reality through the filter of their emotions, experiences, vision on a specific topic, individual in the case of portraits, underlining the subtle elements which represent the subject's psychological features.

Referring to matters related to the modality of interpreting one's personality, the work of Johann Caspar Lavater, Physiognomy, or The corresponding analogy between the conformation of the features and the ruling reassions of the bind: being a complete epitome of the original work of J. C. Lavater, approaches physiognomy as a specific science which explains the connection between one's expression of the face and its shape. A similar endeavour can be noticed also at James A. Russell and José Miguel Fernández-Dols, in The Psychology of Facial Expression, a work in which emotions are corelated with facial, gestical, vocal expressions and body language. Moreover, Patrice Ras in the research "Morphopsychology. The face, the mirror of one's personality", underlines the essential elements referring to morphopsychology and to the ways of studying and understanding the identity of the portrait. The research of these authors opens up the way towards another type of understanding one's countenance, for many artists who are initiated in 
the secrets of rendering physionomy, it is a completion of knowledge and a way of scientific knowledge of the one's psychic and physical features.

\section{Types of portraits}

Alongside these particular elements of morphopsychology and physiognomy, another important aspect is the one related to the evolution of portraiture, correlated with the type of the realized portrait and with the capture method of the model, this requiring a specific framing through the definition of the particular requirements of the concerned image and its functionalities. Starting from various bibliographical sources (West, 2004; Schneider, 2002), a possible typology of the portrait in visual arts would contain the following specific criteria:

- from a thematic point of view - mythological, religious, secular portrait;

- depending on the number of characters and the relationship between themindividual, group, marriage or family portraits ;

- depending on its framing- bust portrait, compositional portrait with hands, full figure portrait ;

- depending on its positioning - profile, half-profile, frontal and from the back portrait ;

- from a functional point of view - the portrait seen as a work of art, as a souvenir, as a biography, as a document, as a political weapon ;

- depending on the gender of the artist - male or female made portraits;

- depending on the gender of the model - male portraits, female portraits, hermaphrodite portraits;

- depending on the age of the model - elder, mature, youngsters and children portraits;

- depending on its destination/motivation - psychological or device portraits;

\section{Examples of psychological portraits}

Regarding psychological portraits, these have offered the artist the possibility to understand and capture the feelings of the models, transposing their features and emotions into an artistic form. Over the history of art, this kind of portrait has experienced an increased interest, 
especially from the side of artists who had a particular inclination towards the psychological field, succeeding in knowing the models and their feelings by overcoming the formal limit of representing the physiognomic features and by attaining the psycho-moral levels of the portrayed characters.

The Portrait of a Young Man, one of the best known psychological portraits created by Lorenzo Lotto (1480-1556), provides various clues for the deciphering of the image, the face placed in a superior position compared to the viewer suggesting the importance of the represented character, while his imposing nature is revealed by his individual physiognomic features in a realistic manner. Despite his age, the superior attitude of the portrayed young man is transmitted through pictorial images and the capture of his direct look, of his clearly defined nose and his half-open mouth, these being just a couple of the particularities of this portrait. The artist used the chromatic to impose a certain distance between the model and the watcher, the powerful contrast between white and black being, in this case, the one which emphasizes both the silhouette of the character, in general, as well as the portrait, in particular.

The typology of the psychological portrait has been completed by one of the representative painters of the $17^{\text {th }}$ century- Rembrandt van Rijn (1606-1669) - whose creations can still reveal the importance that he gave to the physiognomic and characterological study of his characters, almost 4 centuries ago. From his numerous creations, some of the most interesting portraits made by the Dutch master were those of old men, those impressing the viewer through the lack of idealization, the accuracy of details and through the psychological study of the portrayed models. Even in the case of self-portraits, like the one made in 1659, Rembrandt captured his inner drama (Stoleriu, 2013, p. 125), impressing the viewer with his sincere introspection of his feelings, as well as through the sadness etched on his face.

Also, in the painting "Man with a golden helmet", the artist shaped the spiritual dimension of the model, his face and costume being completed in a harmonious way by the chromatic and the Rembrandtian chiaroscuro. Regarding this image, as stated by the Nordic Baroque art specialist Catherine B. Scallen in her work "Rembrandt, the reputation and practice of connaisseurship", the portrait seems isolated in space, Rembrandt 
suggesting the feelings of the model and the swing among sensibility, tenderness, drama and melancholy (Scallen, 2004, p. 168).

Staying in the sphere of realistic representations, we will focus on Russian art, which has also made itself remarked through a series of works in the field of portraiture, rendering expressive and individualized faces in a unique manner, both from a physiognomic and psychological point of view.

Among the numerous Russian artists, in this case we mention Ivan Nikolaevich Kramskoy (1837-1887). Analyzing the ensemble of his portraiture creations, a series of traits easily surfaces, that characterizes both his pictorial style, as well as the specific mechanisms which he used in the shaping of the psychological features of his characters. Beyond his qualities of keen observer and psychologist, Kramskoy also brought forward a special technique of framing the character in the context of origin, which makes the creation of this type of portrait, the psychological one, not exclusively dependent on the rendering of the physiognomic features with precision and talent, reflecting the inner state of the models, but also on the juxtaposition of certain specific elements of the social background these characters come from. Thus, no matter if we talk about an old man coming from the poor class of the society, fact evidenced by his battered clothing, or a aristocratic lady, who betrays her status through her imposing stance and elegant clothing, or even the Czar of Russia, Alexander III, portrayed alongside the symbols of power, this technique is imposed as an ingenious solution of plastic materialization of the most profound psychological traits of the portrayed characters in the works of the mentioned artist.

Alongside these personalities of the universal art, numerous Romanian artists have approached psychological portrait. Among them, we mention only the most important, like Nicolae Grigorescu, Gheorghe Petrascu, Nicolae Tonitza, Corneliu Baba and Dan Hatmanu.

Regarding Nicolae Grigorescu (1838-1907), he has been remarked as a valuable artist of modern Romanian art - of neoclassic formation (Niculescu, 1956, p. 132) -, who has evidenced himself through sceneries and female portraits, which have constituted an important chapter of his creation, paying special attention to the reconstruction of the physiognomic features and of the national costume. From his creation, "Fetita cu basma rosie" (The girl with a red kerchief) is part of the collection of psychological portraits, evoking the 
essence of childhood and the innocence specific to this age. The mastery of the artist is revealed by his unique way of disposing colors, through the refinement of light and shadow contrasts, which define the "mignon" face of the girl, her black, big and piercing eyes, her white face respectively, framed by a red traditional kerchief, specific to past traditional clothing.

Another example of psychological portrait is found in the painting "Prizonieri turci" (Turkish prisoners), in which the artist has studied (Jianu and Frunzetti, 1953) the expression and intensity of the feelings of the two characters, artistically expressing their different way of reacting in similar contexts. In the case of the prisoner from the right side of the image, Grigorescu captures his pained and resigned attitude, while, in an extremely suggestive manner, his comrade's face transmits a complexity of feelings from which hatred, revolt, unease and disorientation (Jianu and Frunzetti, 1953) are remarked. Those feelings have been suggested by the succession of plans, evidenced with the help of the chiaroscuro of Rembrandtian influence and by the restricted chromatic, which conveys and intensifies the dramatic atmosphere of the work.

Moreover, through examples of his creation, Nicolae Tonitza (1886-1940) offers the proof of an extraordinary understanding and representation of the human face, being placed, through his innovative vision, at the limit between realism, postimpressionism and expressionism. He has even addressed the art of caricature, through which he has managed to point out "the physical or moral, political or social, faults and monstrosities" (Pavel, 1963, p. 5).

However, what we thought graded the value of this great Romanian painter, is his very quality of being a good observer, fact evidenced especially in his psychological portraits, which often illustrated the theme of childhood, the specific features of this age, the purity of the calm, serene faces and the deep eyes (Sava, 2010, p. 250) of his characters. Besides, the big, black eyes, the major point of interest of the entire portrait have become a true particularity of Tonitza's portraitures, his works often being recognizable also due to this aspect. To demonstrate this quality for psychological portrayal, we remind, from the creation of the artist, just one of his works made in his most intense creative period, entitled "Catiusa lipoveanca", a representative example for 
the child portrait type, capable of showcasing the gentleness and softness of the age (Pavel, 1963, p. 24).

As it has been evidenced through the couple of examples given, the portraiture of the Romanian artists from the Modern Age makes itself remarked both through an individualized treatment of physiognomic features and a careful speculation of the psychological depths of the represented models, aspects which, in this context, present an integrator characteristic of those creations in the more complex universal artistic phenomenon.

\section{Conclusions}

We can shortly state that the portrait, like decorative arts in general, has suffered multiple transformations, showcasing its importance in various social media, in time becoming one of the major preoccupations of artistic creation. Making use of the tendencies of the ages they belonged to, portraits have often been seen as a unique way of remembering, venerating or satirizing the emblematic characters of history, trying to capture and interpret the experience of the models, through processes of documentation and synthesis of the creative visions specific to a particular age.

Furthermore, the scientific particularities open new horizons of knowledge and interpretation for portraiture, the concerned science proving useful both for the creator as well as the viewer, both benefiting from the understanding of the complex relationship among the character, individuality and personality of the model.

To sum up, we believe that the main function of the psychological portrait is that of memento, seeking to retrieve in actuality the image and personality of the represented model, this finality being conditioned to a great extent by the psychologist-like abilities of the artist. All these elements have contributed to the identification of some similarities on many levels - in this case, the psychological and visual one - between the portrayed human being and the creation. Therefore, the portrait asserts itself as a possible connection between two very different domains, psychology and art, the result being an interdisciplinary approach of the human figure. 


\section{References}

Jianu, I. and Frunzetti, I. (1953). Maestrii picturii romanesti in Mureul de Arta al Republicii Populare Romane, "Editura de Stat pentru Literatură si Arta" Publishing House.

Nadeije Laneyrie-Dagen, N. (2004). Pictura - secrete si dęvaluiri, Rao Publishing House, Bucharest.

Niculescu, R. (1956). Grigorescu intre Clasicism si Neoclasicism. Studii si cercetari de istoria artei, The "Academia Republicii Populare Române" Publishing House, Bucharest.

Onofrei, P. A. (2008). Narrative techniques in THE PORTRAIT OF A LADY by Henry James - a psychoanalytic approach. Arta si publicul nou, Editura Artes Iasi.

Pavel, A. (1963). Nicolae Tonitra, Meridiane Publishing House, Bucharest.

Perkinson, S. (2009). The Likeness of the King: A Prehistory of Portraiture in Late Medieval France, The University of Chicago.

Sava, V. (2010). Portretul modern in pictura romaneasca aflata in patrimoniul Muzeului de Arta de la Iasi, Artes Publishing House.

Scallen, C. B. (2004). Rembrandt, reputation, and the practice of connaisseurship, Amsterdam University Press, Amsterdam.

Schneider, N. (2002). The art of the portrait, Taschen Publishing House.

Stoleriu, A. (2013). Reprezentarea vizuala a sacrului, Institutul European Publishing House, Iasi.

West, S. (2004). Portraiture, Oxford University Press.

\section{Biodata}

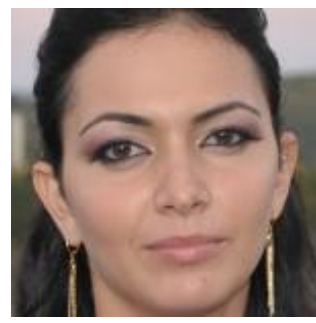

Irina-Andreea STOLERIU is an art historian, born in Iaşi in 1983. She is a Phd in art history, at the University of Arts "George Enescu" Iasi (Faculty of Fine Arts and Design). She is a Lecturer in the Department of Art History and Theory of the same faculty. She is the author of several articles published in different national or international journals. As a visual artist, she has participated in various personal or collective art exhibitions in Romania or outside the country.

Stoleriu, I-A. (2015). The Portrait. A Possible Connection between Psychology and Art. Logos, Universality, Mentality, Education, Novelty - Section Philosophy and Humanistic Sciences, III (1), 139-148. 